\title{
Evaluating the Organoleptic Properties of Soy Meatballs (BEEF) with varying Levels of Moringa oleifera Leaves Powder
}

\author{
* ${ }^{1}$ EVIVIE, SE; EBABHAMIEGBEBHO, PA, IMAREN, JO; IGENE, JO \\ ${ }^{1}$ Key Laboratory of Dairy Science-Ministry of Education (KLDS-MOE), College of Food Sciences, Northeast Agricultural University, \\ Harbin 150030 PR China \\ ${ }^{2}$ Food Science and Nutrition Unit, Department of Animal Science, Faculty of Agriculture, University of Benin, PMB 1154, Benin City, \\ Nigeria. \\ *Corresponding Author's email: Besta_intercom@yahoo.com
}

\begin{abstract}
The study was conducted to evaluate the organoleptic properties of soy meatball at varying levels of Moringa oleifera leaves powder inclusion. The result of the sensory evaluation of the products showed that they were generally accepted above average (3.5). However, soy meatball sample without Moringa oleifera leaves powder inclusion was most acceptable (very much liked) in terms of colour, taste, texture and overall acceptance with a mean score of 4.37. The colour scores were significantly different $(\mathrm{P}>0.05)$. Generally, the taste decreased with Moringa oleifera leaves powder inclusion and differ significantly $(\mathrm{P}>0.05)$. ( ) JASEM
\end{abstract}

http://dx.doi.org/10.4314/jasem.v19i4.12

KEY WORDS: Meatball, Soy flour, Malnutrition, Moringa oleifera, Sensory evaluation, Yield

\section{INTRODUCTION}

The global increase in health risk which has been attributed to unhealthy feeding habits and as a result, large population of different nations are now conscious of what enters their biological systems (Batool and Hafeez, 2012). To counter this trend, several non meat ingredients have been evaluated as meat replacements in meat products with the goal of maintaining the products yield and minimizing formulation cost while retaining acceptable palatability (Arun et al., 2008) Protein is an essential macronutrient needed by the human body for growth and maintenance. Foods rich in animal protein are meat, fish, eggs, poultry, and dairy products, while plant foods high in protein are mainly legumes, nuts, and grains (Delimaris, 2013). Meat is held in high esteem in most communities. It has prestige value, it is often regarded as the central food round which meals are planned and from the popular as well as the scientific point of view, it is regarded as a food of high nutritive value (FAO, 2015).

Meatballs can be defined as round meat foods obtained from the meat (cattle, duck, goat, chicken) that have been mashed and mixed with other additives in order to formulate a product that is better, affordable, more accessible, acceptable and healthy. They are animal products with high water content. The main ingredient in making meatballs is the meat - beef, chicken, shrimp, fish and ducks. Soybean meal can improve the quality of food (Novia et al., 2013). There are many kinds of meatball recipes using different kind of meats and ingredients.
Some are made of meat to and ingredients to cement the ball, others are meatless to satisfy vegetarian. The processes and methods of making meat balls depend on one's cultural background and individual taste. Several works have been carried out on the development and evaluation of the economic benefits of meatball in Africa, incorporating other ingredients such as soy flour to improve its quality and acceptability (Igene et al., 2012, Odiase et al., 2013). The recent researches on meatball have strongly suggested that it can play a vital role in fighting protein malnutrition in sub-Sahara Africa in particular, incurring minimal costs in the process.

Soy products have been referred to as healthy and functional foods - products such as flours, textured soy protein, concentrates and isolates are economical source of food proteins. (Hossein, 2011). They are used in meat products as a binder for improving yields, as a gelling agent to enhance emulsion stability and as meat replacement to reduce cost (Lecomte et al., 1993; Rentfrow et al., 2004). The health benefits of soy in meat include prevention of heart diseases, cancer, high blood pressure, diabetesrelated disease and many others. Soy bean oil is rich in fatty acids and devoid of cholesterol. It is an excellent source of calcium, iron, and vitamins such as niacin, thiamin and riboflavin. Soy bean contains all essential amino acid apart from methionine and tryptophan. These amino acids closely match those required for humans (Russell, 2004; Sacks et al., 2006). Soy-meat may also help with menopause symptoms and osteoporosis. Soy bean contains an 
impressive array of phytochemicals (biologically active components derived from plants (Sacks et al., 2006), which are beneficial to human nutrition.

The Moringa oleifera plant is highly valued since almost every part of it (leaves, roots, barks, fruits, flowers etc.) is used as food with high nutritional value (Anwar et al., 2007, Chuang et al., 2007). It is thus not surprising that research into its medicinal and nutritional usefulness have intensified in the last decade in Nigeria. The leaves of Moringa oleifera are considered to give immense possibilities for those who are nutritionally challenged and may be regarded as a protein and calcium supplement. It also contains a unique blend of phytochemicals, glucosinolates and isothyiocyanates which are reported to have antihypertensive, anticancer, antibacterial and antibacterial effects (Aminashaun et al., 2013, Rajangam et al., 2001, Nickson et al., 2003). As a traditional food in Africa, it has the potential to improve nutrition, boost food security, foster rural development and support sustainable land care (NRC, 2006). Moringa oleifera marinade has been used to protect stored smoke-dried catfish from microbial spoilage thus limiting economic loss and possible health risks to consumers. (Adeyemi et al 2013). Other importance of the plant include antispasmodic (Caceres et al., 1992), diuretic (Morton, 1991), antihypertensive (Dahot, 1988), cholesterol lowering (Mehta et al., 2003), antioxidant, ant - diabetic and hepatoprotective properties (Ruckmani et al., 1998).

In view of these, it becomes necessary to carry out research on the inclusion of moringa leave in soy meatball at varying levels. This will evaluate the synergistic effects of the various ingredients and draw a correlation with consumers' perception of the product so formulated. The objectives of this study therefore are to evaluate the organoleptic properties of soy meatball made from beef, at varying levels of Moringa oleifera inclusion and determine the most acceptable level of Moringa oleifera inclusion for soy meatballs made from beef.

\section{MATERIALS AND METHODS}

Source of Raw Materials: The experiment was carried out in the Faculty of Agriculture Main Laboratory, University of Benin, Nigeria. Beef (3 kg) was purchased from New Benin market. The connective tissues were trimmed off after which it was washed and stored in a deep freezer until when needed. Moringa oleifera leaves were harvested from the Moringa tree in the Department of Crop Science Experimental Research Farm, Faculty of Agriculture, University of Benin. It was then processed into
Moringa oleifera powder as shown in Plate 2. Other ingredients such as soy flour and the condiments used were purchased from New Benin market. The soy flour was processed as described by Odiase et al. (2013).

Experimental Treatments Five different combinations of Moringa/Soybeef mix were investigated in this study, each in three replications. The combinations were: (i) 0/100\% Moringa/Soybeef mix (control), (ii) $1 / 99 \%$ Moringa/Soybeef mix, (iii) $2 / 98 \%$ Moringa/Soybeef mix, (iv) 3/97\% Moringa/Soybeef mix, 4/96\% Moringa/Soybeef mix, and (v) 1Soy Meatball

Moringa Soy Meatball Formation: The stored beef were thawed at room temperature $\left(26 \pm 20^{\circ} \mathrm{C}\right)$ and was ground using Monlinex meat mincer, Model (Hv6). The Moringa leaves were processed into moringa powder by sorting freshly harvested Moringa leaves, oven-drying at $70^{\circ} \mathrm{C}$ for $45 \mathrm{~min}$ and ground into powder form. The Moringa Soy meatball mix was produced by substituting soy beef with moringa powder at $1 \%, 2 \%, 3 \%$ and $4 \%$ for beef. Soy beef mix without moringa powder was used as the control. Blue flame produced by a medium sized gas cooker was used. The soy-beef mix was manually rolled into small balls of $4 \mathrm{~cm}$ in diameter each (Plate. 3 A, B). In other to reduce bias, condiments and soy flour were of equal proportions in the individual mix formulation resulting into $200 \mathrm{~g}$ per mix. The formed balls were then fried in hot vegetable oil using deep fat fryer at $170^{\circ} \mathrm{C}$ (model $\mathrm{PH}-515$ ) for $4 \mathrm{~min}$. Details of the mix is as shown in Table 1.

Proximate Analysis: The fried samples were analyzed for moisture, ash, ether extract, protein and carbohydrate (NFE) as described by AOAC (2002).

Organoleptic (Sensory) Evaluation: Five samples were coded and presented to a semi-trained sensory panel made up 20 judges to evaluate samples according to degree of likeness in respect to colour, taste, texture and overall acceptance. Water and cracker biscuits were served in between samples assessment to enable panellists rinse properly and neutralize carryover flavours. Panellists were served in their separate locations far away from the sample cooking and preparation room and samples were coded to reduce bias. A 5-point hedonic scale having 5 (like extremely) as the highest score and 1(dislike extremely) as the lowest score was used according to the procedure described by Watts et al. (1989). 
Table 1: Mix formulation of Moringa Soy meatball

\begin{tabular}{|c|c|c|c|c|c|c|c|}
\hline \multirow[t]{2}{*}{ Ingredients } & $\begin{array}{l}\text { Levels of Moringa } \\
\text { /soy beef }(\%)\end{array}$ & 0.1 & 0.2 & 0.3 & 0.4 & 0.5 & Total \\
\hline & & $0 / 100 \%$ & $1 / 99 \%$ & $2 / 98 \%$ & $3 / 97 \%$ & $4 / 96 \%$ & \\
\hline Moringa & 75 & 0 & 2 & 4 & 6 & 8 & 20 \\
\hline Beef & & 150 & 148 & 146 & 144 & 142 & 730 \\
\hline Soy flour & 10 & 20 & 20 & 20 & 20 & 20 & 100 \\
\hline Salt & 0.25 & 0.5 & 0.5 & 0.5 & 0.5 & 0.5 & 2.5 \\
\hline Water & 1 & 2 & 2 & 2 & 2 & 2 & 10 \\
\hline Red pepper & 0.4 & 0.8 & 0.8 & 0.8 & 0.8 & 0.8 & 4 \\
\hline Thyme & 0.15 & 0.3 & 0.3 & 0.3 & 0.3 & 0.3 & 1.5 \\
\hline Curry & 0.65 & 1.3 & 1.3 & 1.3 & 1.3 & 1.3 & 6.5 \\
\hline Ginger & 0.65 & 1.3 & 1.3 & 1.3 & 1.3 & 1.3 & 6.5 \\
\hline Onion & 3.3 & 6.6 & 6.6 & 6.6 & 6.6 & 6.6 & 33 \\
\hline $\begin{array}{l}\text { Seasoning } \\
\text { cube }\end{array}$ & 1.75 & 3.5 & 3.5 & 3.5 & 3.5 & 3.5 & 17.5 \\
\hline $\begin{array}{l}\text { Cassava } \\
\text { starch }\end{array}$ & 5.75 & 11.5 & 11.5 & 11.5 & 11.5 & 11.5 & 57.5 \\
\hline Sugar & 1.1 & 2.2 & 2.2 & 2.2 & 2.2 & 2.2 & 11 \\
\hline Total & $100 \%$ & $200 \mathrm{~g}$ & $200 \mathrm{~g}$ & $200 \mathrm{~g}$ & $200 \mathrm{~g}$ & $200 \mathrm{~g}$ & $1000 \mathrm{~g}$ \\
\hline
\end{tabular}

Weight Loss and Yield Determination: The weight of Moringa soy beef mix and fried balls were taken and weight loss (\%) and yield were calculated as described by Odiase et al. (2013). The number of meatballs produced per treatment was also determined.

Statistical Analysis: The data obtained for the different level of inclusion of Moringa oleifera was analysed using Genstat (12 ${ }^{\text {th }}$ Edition) and significant treatment means were separated by Duncan Multiple Range test as described by Alika (2006).

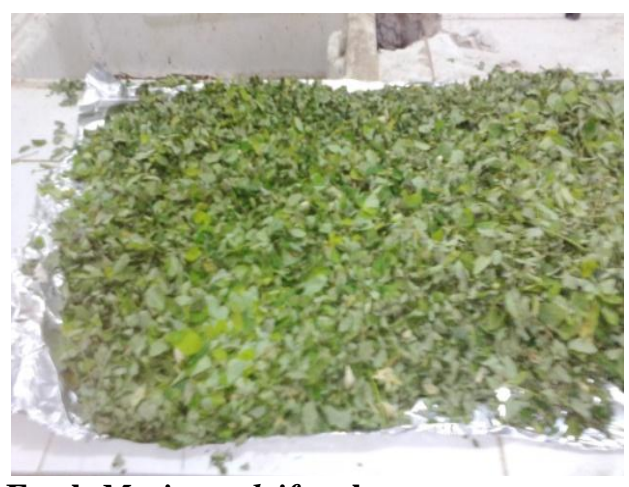

Fresh Moringa oleifera leaves

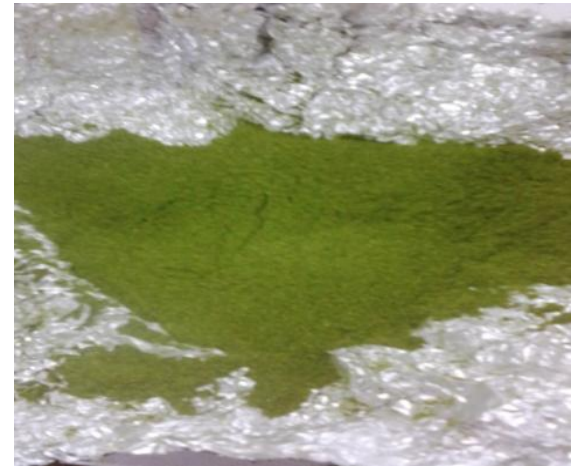

Sieving ground Moringa oleifera

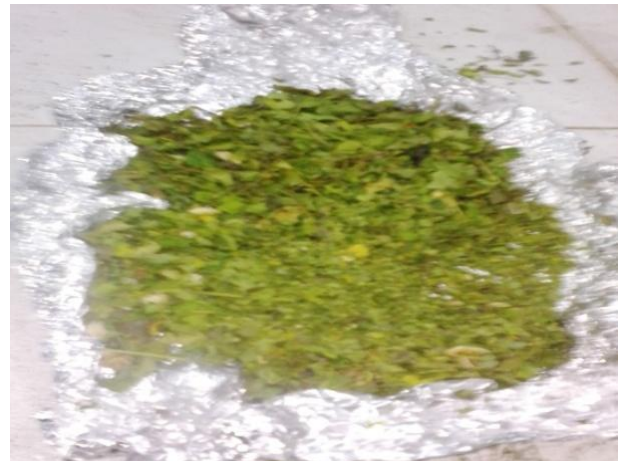

Dried Moringa oleifera leaves

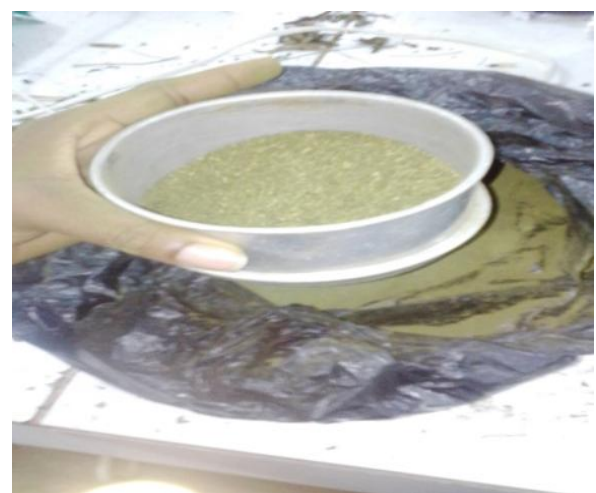

Moringa oleifera leaves powder

PLATE 2: Preparation of the Moringa oleifera Leaves powder 


\section{RESULTS AND DISCUSSION}

Table 2: Weight loss and yield per ball

\begin{tabular}{cccccc}
\hline Samples & $\begin{array}{c}\text { Weight before } \\
\text { frying }(\mathrm{g})\end{array}$ & $\begin{array}{c}\text { Weight after } \\
\text { frying }(\mathrm{g})\end{array}$ & $\begin{array}{c}\text { Weight loss } \\
(\mathrm{g})\end{array}$ & $\begin{array}{c}\text { Weight } \\
\text { loss } \\
(\%)\end{array}$ & Yield (\%) \\
\hline $\mathbf{0 \%}$ & 9.85 & 7.72 & 2.13 & 21.60 & 78.37 \\
$\mathbf{1 \%}$ & 8.64 & 6.56 & 2.08 & 24.07 & 75.93 \\
$\mathbf{2 \%}$ & 8.91 & 6.94 & 1.97 & 22.11 & 77.89 \\
$\mathbf{3 \%}$ & 9.71 & 7.80 & 1.91 & 19.67 & 80.33 \\
$\mathbf{4 \%}$ & 9.05 & 7.35 & 1.70 & 18.78 & 81.21 \\
\hline
\end{tabular}

Note: Meatball diameter $=4 \mathrm{~cm}$

The results of effects of varying level of Moringa inclusion on weight loss and yield parameters are as shown in Table 2. There was a reduction in weight loss of samples with 0\% Moringa oleifera inclusion $(21.60 \%)$ to samples with $4 \%$ inclusion level $(18.78 \%)$. The yield increased as the level of
Moringa inclusion increased, suggesting a direct variation between the two parameters. Moringa inclusion increased the cooking yield by an average value of $78.75 \%$. There were significant differences $(\mathrm{P}<0.05)$ between the weights of the Moringa soy meatball due to frying

Table 3: Treatment means of sensory evaluation for fried soy meatballs

\begin{tabular}{ccccc}
\hline $\begin{array}{c}\text { Fried soy meatball } \\
\text { (with Moringa inclusion levels) }\end{array}$ & Colour & Taste & Texture & $\begin{array}{c}\text { Overall } \\
\text { acceptance }\end{array}$ \\
\hline $0 \%$ & $4.70^{\mathrm{a}}$ & $4.29^{\mathrm{a}}$ & $4.13^{\mathrm{a}}$ & $4.38^{\mathrm{a}}$ \\
$1 \%$ & $3.86^{\mathrm{b}}$ & $4.05^{\mathrm{b}}$ & $3.45^{\mathrm{b}}$ & $3.90^{\mathrm{b}}$ \\
$2 \%$ & $2.60^{\mathrm{c}}$ & $3.47^{\mathrm{c}}$ & $3.77^{\mathrm{c}}$ & $3.79^{\mathrm{b}}$ \\
$3 \%$ & $2.78^{\mathrm{c}}$ & $3.07^{\mathrm{d}}$ & $3.58^{\mathrm{c}}$ & $2.81^{\mathrm{c}}$ \\
$4 \%$ & $2.25^{\mathrm{c}}$ & $2.85^{\mathrm{e}}$ & $3.03^{\mathrm{d}}$ & $2.87^{\mathrm{c}}$ \\
\hline SEM & $\mathbf{0 . 0 5 9 4}$ & $\mathbf{0 . 0 5 0 9}$ & $\mathbf{0 . 0 5 5 8}$ & $\mathbf{0 . 0 5 7 0}$ \\
\hline
\end{tabular}

Mean superscripted by the same alphabet within columns are not significantly different $(\mathrm{P}<0.05)$. Each parameter is expressed as mean \pm SEM (Standard Errors of Means).

In the sensory evaluation, the colour scores were significantly different $(\mathrm{P}<0.05)$ except in the samples of $2 \%, 3 \%$ and $4 \%$ which were significantly the same (Table 3). However, the value for colour at $0 \%$ Moringa inclusion was highest (4.70) than that of $4 \%$ Moringa inclusion which was the lowest (2.25). There was no significant difference in the colour, taste and texture $(\mathrm{P}<0.05)$ of the $2 \%$ and $3 \%$ Moringa soy meatballs but were significantly different $(\mathrm{P}>0.05)$ in their overall acceptance. Generally, the taste decreased with increased inclusion of Moringa oleifera and differs significantly $(\mathrm{P}>0.05)$. Soy meatballs with $0 \%$ Moringa oleifera inclusion level had the highest taste score (4.29) and those with the highest inclusion level of $4 \%$ had the lowest average taste score (2.85). Though the texture also decreased as the level of Moringa inclusion increased, there were no significant differences $(\mathrm{P}>0.05)$ between $2 \%$ and $3 \%$ Moringa oleifera inclusion

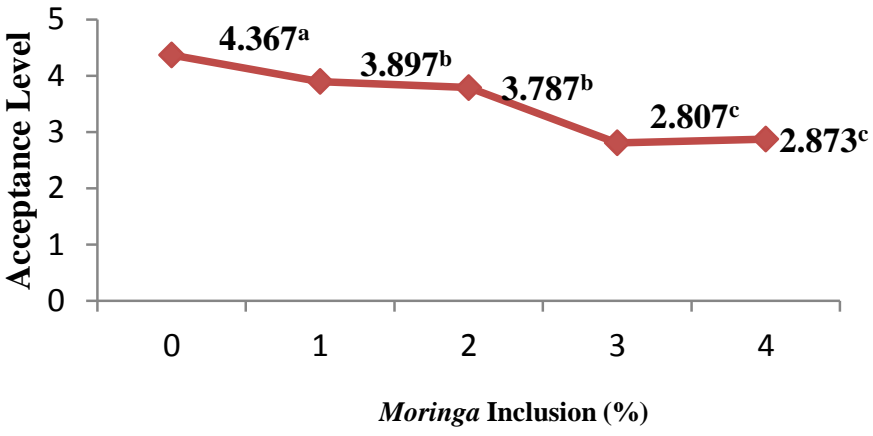

Fig 1: Overall acceptability of Moringa oleifera inclusion level in soy meatball 
An inverse relationship was observed between consumers' overall acceptance of the soy meatball samples with increasing inclusion levels of Moringa oleifera (Fig 1). Soy meatballs with 0\% Moringa oleifera inclusion were most acceptable (score = 4.38) while samples with $3 \%$ inclusion was the least accepted $($ score $=2.81)$. The average score for the $3 \%$ Moringa oleifera soy meatball was significantly different $(\mathrm{P}<0.05)$ from the $4 \%$ inclusion. There were no significant differences $(\mathrm{P}>0.05)$ between the $0 \%$ and $1 \%$ Moringa inclusion as well as $2 \%$ and $3 \%$ in terms of overall acceptance (Table 4.3).

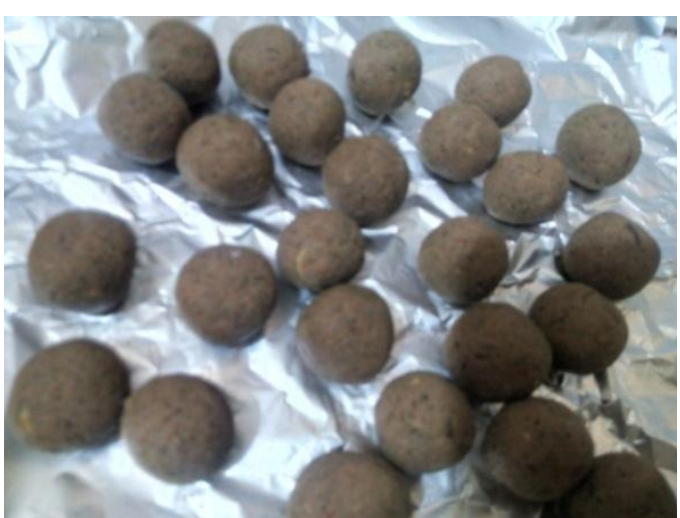

0\% Moringa Soy meatballs before Frying

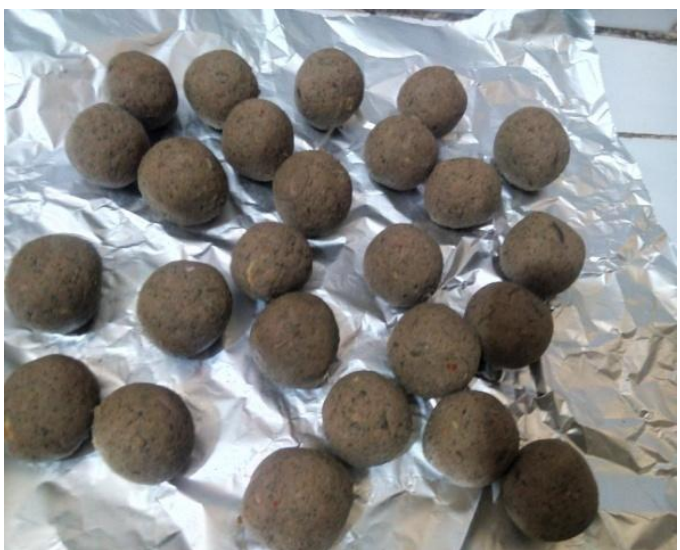

1\% Moringa Soy meatballs before Frying

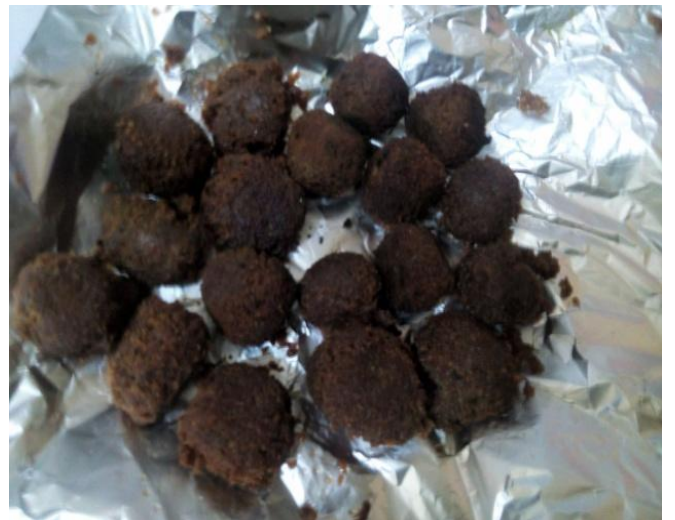

0\% Moringa Soy meatballs after Frying

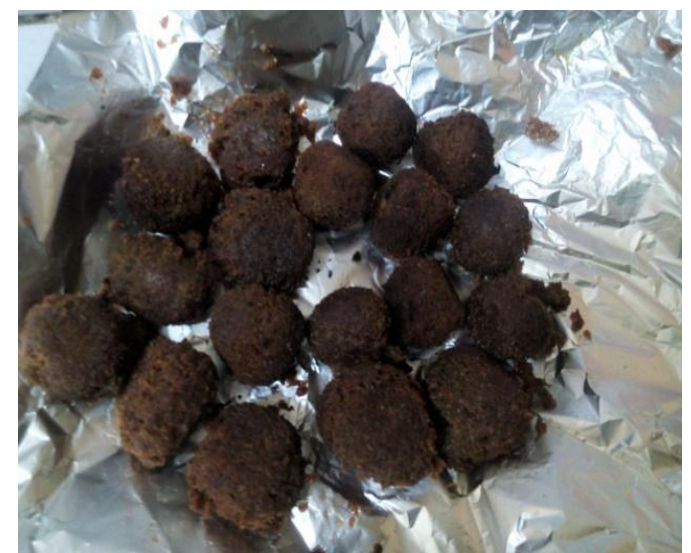

1\% Moringa Soy meatballs after Frying

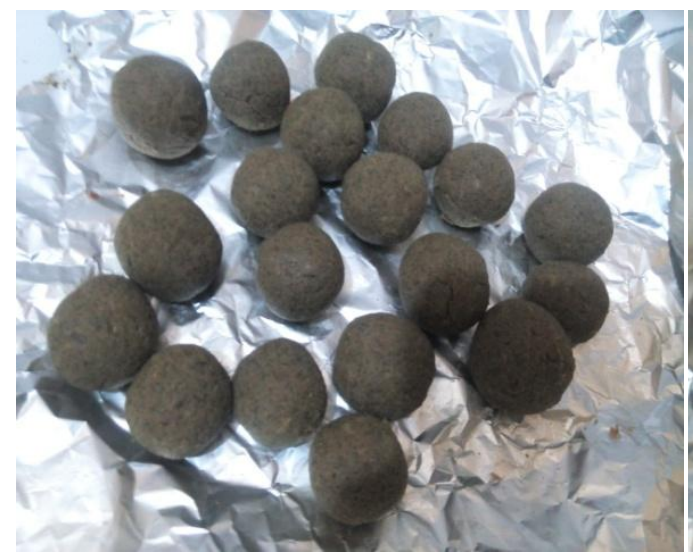

2\% Moringa Soy meatballs before Frying

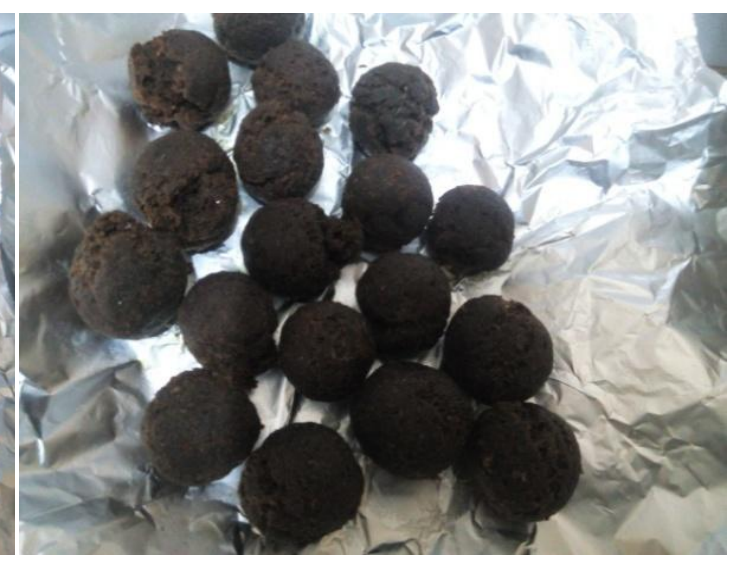

2\% Moringa Soy meatballs after Frying

PLATE 3(A): 0 - 2\% Moringa Soy meatball samples before and after Frying 


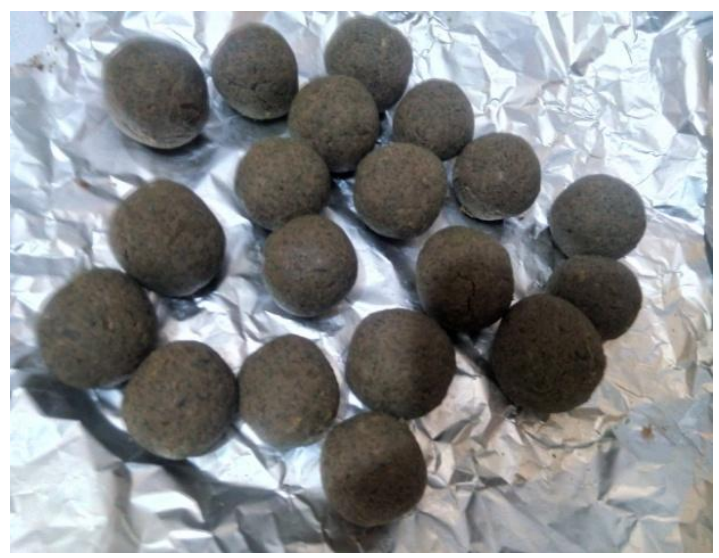

3\% Moringa Soy meatballs before Frying

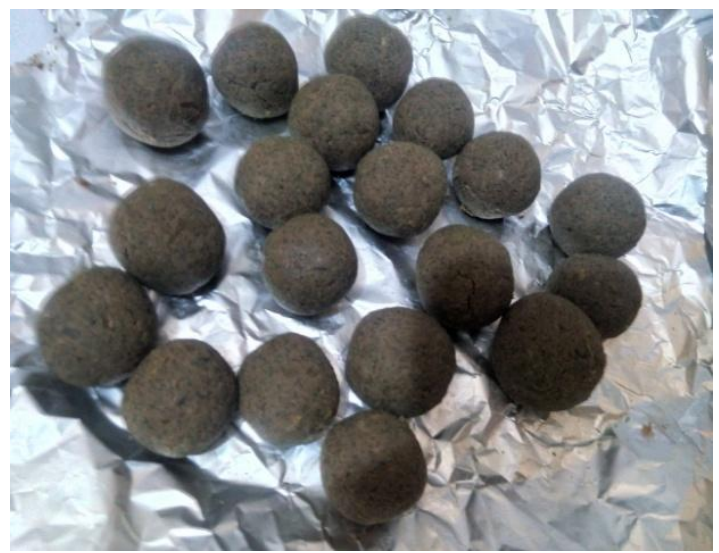

4\% Moringa Soy meatball before Frying

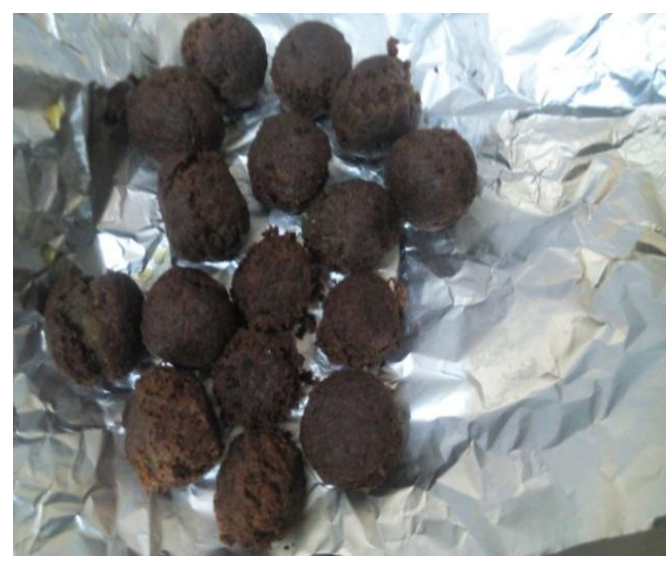

3\% Moringa Soy meatballs after Frying

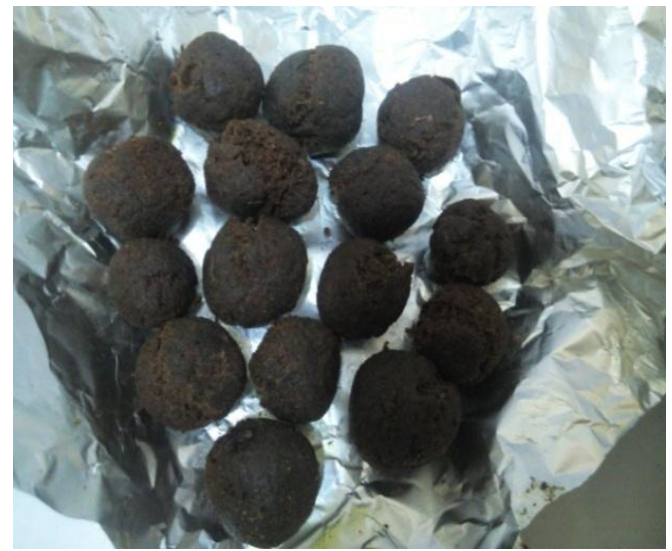

4\% Moringa Soy meatballAfter Frying

PLATE 3(B): 3 - 4\% Moringa Soy meatball samples before and after Frying

The effects of varying Moringa inclusion on weight loss and yield parameters showed that moringa inclusion increased the cooking yield by an average of $78.75 \%$. There were significant differences $(\mathrm{P}<0.05)$ between the weights of the Moringa soy meatball due to frying. This result suggests an inverse relationship between Moringa inclusion levels and weight loss. A similar trend was reported by Lecomte et al., (1993) that cooking yield represents the retention of water and solutes during processing of food products. Ray et al (1981) also observed significant increase $(\mathrm{P}<0.05)$ in cooking yield up to $26 \%$ soy concentration in his study using ground beef. According to Scheiwger (1974), soy protein is commonly used in processed meat as a binder to reduce processing cost and increase yield. The trend in weight changes showed an increase in weight due to the increasing ability of the soy flour to bind moisture. This is consistent with the finding of Vaisey et al. (1975) that replacement of meat with legumes resulted in reduction of drip losses. Soy protein and Moringa oleifera contributes to the nutritional and overall eating quality of meat products
(Waggle et al., 1981; Otunola et al., 2013). The weight loss-yield relationship observed in this study also agrees with the findings of Odiase et al. (2013). The highest yield in this study is however lower than that of uncured and un-spiced meat ball samples prepared in an earlier study by Igene et al. (2012) as well as for $25 \%$ soy meatballs reported by Odiase et al. (2013), thus suggesting that there may be other factors which determine the yield of a sample. These range from length of thawing, frying, steaming and quantity of oil used.

In the sensory evaluation, the colour scores were significantly different $(\mathrm{P}<0.05)$ except that of $2 \%, 3 \%$ and $4 \%$ which were not significantly different $(\mathrm{P}>0.05)$ (Table 3). However, the value for colour at $0 \%$ Moringa inclusion was highest with an average of 4.7 , while that of $4 \%$ moringa inclusion was lowest with an average score of 2.25 . This finding is similar to the report of Odiase et al., (2013) who reported that an increase in soy flour of the meatball sample resulted in a significant $(\mathrm{P}>0.05)$ decrease in mean colour score. In processing, colour has been 
identified as the single most important factor of meat products that influences consumer buying decision and affects their perception of the freshness of the product (Boles and Pegg, 2005). This thus suggests that adding suitable colorants to Moringa soy flour meatballs may significantly improve its overall acceptance as the highest inclusion level may have the highest synergistic effects of all the samples prepared in this study.

Mean taste and texture scores decreased significantly $(\mathrm{P}>0.05)$ as moringa inclusion level increased. This finding agreed with Otunola et al., (2013), when the cookies without moringa leave waste (MLW) were superior in taste compared to those substituted with $5 \%$ and $10 \%$ MLW. This may be as a result of the not too pleasant taste of the moringa leaves powder. This study however anticipated that the highest Moringa inclusion levels will be most accepted. The inverse relationship between texture/taste and Moringa inclusion levels is also similar to the findings of Odiase et al., (2013) who investigated soy flour inclusion levels in meatballs. Though the texture decreased with increased Moringa oleifera inclusion, there were no significant difference $(\mathrm{P}<0.05)$ between $2 \%$ and $3 \%$ Moringa oleifera inclusion levels. Irrespective of the colour, taste and texture, the products were generally accepted above average. The most acceptable of the products was the 0\% Moringa oleifera inclusion. Even though, 3\% inclusion was least acceptable, it was not significantly different $(\mathrm{P}<0.05)$ from $4 \%$ inclusion. There were no significant differences $(\mathrm{P}<0.05)$ between $1 \%$ and $2 \%$ Moringa oleifera inclusion in terms of overall acceptance. The inclusion of colorants and other ingredients like sweeteners to higher inclusion levels of the soy meatball samples may improve its overall acceptability as well as nutritive and health benefits to consumers.

In view of the promising synergistic effects of the Moringa soy meatball combination, it is therefore important that advances in research and development of soy meat combinations that has significant value in the fast food industry be made, especially in Nigeria and other developing countries where animal products supply is a major challenge. This shortage is reaffirmed in a 2015 FAO report that the per caput consumption of meat in developing countries, including Nigeria, must be considered insufficient and results in under-nourishment and malnutrition. This becomes imperative as the nation, endowed with diverse livestock species, strives towards a more advanced global economy and majority of its teeming population depend on processed food products on a daily basis. This will contribute in large measures to curb incidences of acute malnutrition in Nigeria and, in the long run, the sub-Saharan region of the continent (Igene et al., 2012; Odiase et al., 2013). There is also the need for researches on the safe dosage of Moringa oleifera application to human diet to be carried out and appropriate recommendations made.

Conclusion: Meatball is a convenience food product that has the propensity to play a crucial role in the fight against protein malnutrition in tomorrow's Nigeria and sub-Sahara Africa. This study has shown that soy meatballs with or without Moringa oleifera leave powder were generally accepted, but the soy meatballs without Moringa oleifera inclusion were most acceptable. It is therefore important that advances in research and development of soy meat combination that has significant value in the fast food industry be made, especially in Nigeria and other developing countries where animal products supply is a major challenge. It is also imperative that researches into the safe dosage of Moringa oleifera application to human diet should be carried out and appropriate recommendations made.

\section{REFERENCES}

Arun, K.D., Anne, S.R.A., Arun, K.V. and Napa, K. (2008). Physioco-chemical,textural, sensory characteristics and storage quality of goat meat patties extended with full fat soy paste and soy granules. International Journal of Food Science and Technology, 43, 383-392.

Adeyemi, K.D., Ahmed El-Imam, A.M., Dosunmu, O.O. and Lawal, O.K. (2013). 104 effects of Moringa oleifera marinade on microbial stability of smokedried african catfish (Clarias gariepinus). Ethiopian Journal of Environmental Studies and Management, 6: 1.

Association of Official Analytical Chemists (AOAC) (2002). Official Methods of Analysis. 17th edn Washington DC.Association of Official Analytical Chemists.

Batool, W. and Hafeez, M. G. (2012). Unhealthy eating habits. Kemocolian Journal of Medical Sciences

Boles, J.A. and Pegg, R. (2005). Meat colour. Montana State University and Saskatchewan food product innovation programme, University of Saskatchewan.

Caceres, A., Saravia, A., Rizzo, S., Zabala, L., Leon, E. D. and Nave, F (1992). Pharmacological properties ofMoringa oleifera: screening for antispasmatic, antiinflammatory and diuretic activity. J. Ethnopharmacol $36: 233-237$ 
Dahot, M.U. (1988) Vitamin contents of flowers and seeds of M. oleifera. Pak. J. Biochem.

21:1-24.

Delimaris, I. (2013). Adverse Effects Associated with Protein Intake above the Recommended Dietary Allowance for Adults. ISRN Nutrition. 126929: 6

FAO (2015). Meat and meat products in human nutrition in developing countries. Available at http://www.fao.org/ag/againfo/themes/en/meat/backgr ound.html. Accessed on 12/02/2015

Hossein, J. (2011). Soy Products as Healthy and Functional Foods. Middle-East Journal of Scientific Research. 7 (1): 71-80

Igene, J.O., Akinjobi, K.S. and Evivie, S.E. (2012). Preliminary studies on the development of meatballs. J. Appl. Sci. \& Env. Manag. 16(2):167-170

Lecomte, N.B., Zayas, J.F and Kastner, C. L (1993). Soy protein functional and sensory characteristics in comminuted meats. Journal of food Science, 58: 464 467.

Mehta, L. K., Balaraman, R., Amin, A.H., Batfa, P.A. and Gulati, O.D.(2003) Effect of fruits of M. oleifera on the lipid profile of normal and hypercholesterolaemic rabbits. J. Ethnopharmacol. 86: 191-195.

Morton , J.E.(1991) The horseradish tree, Moringa pterygosperma( Moringaceae )- a boon to arid lands.Economic Botany. 45(3): 318-333.

National Research Council (2006). "Moringa". Lost Crops of Africa: National Academies Press. Vol. II.

Novia D., Juliyarsi I., Melia S. and Vermalida, W.A. (2013). Substitution of Soybean Meal and Cornmeal to Moisture, pH, Bacterial Colony Forming and Shelf Life of Rejected Duck Meatballs. International Journals of Advance Science Engineering Information Technology. 3 (4):35-39.

Odiase, M.O., Igene, J.O., Evivie, S.E. and Ebabhamiegbebho, P. A. (2013). Determination and sensory evaluation of soy flour-meat combinations in the production of meatballs. Journal of Applied and Natural Science 5 (2): 482-487

Otunola, G.A., Arise, A.K., Sola-Ojo, F. E., Nmom, I.O. and Toye, A.A. (2013). The effects of addition of Moringa leaf waste fibre on proximate and sensory characteristics of cookies. Agrosearch, 13(1): $69-75$.
\Rajangam, J., Manavalan, R.S.A., Thangaraj, T., Vijayakumar A. and Muthukrishan, N. (2001). Status of production and utilisation of Moringa in southern India. Development Potential for Moringa Products. Dar Es Salaam, Tanzania. http://www.moringanews.org/actes/rajangam_en.doc.

Ray, F.K. Parret, N.A., Vanstavern, B.D. and Ockerman, H.W. (1981). Effect of Soy Level and Storage Time on the Quality Characteristics of Ground Beef Patties. J. Food Sci. 46:1 162-1164

Rentfrow, G., Brewer, M.S., Weingartner, K.E and Mckeith, F.K. (2014). Sensory characteristics of beef and pork processed meats containing non-solvent extracted texturized soy protein. Journal of Muscle Foods. 15: 225-234

Ruckmani, K., Kavimani, S., Anandan, R. and Jaykar, B.( 1998) Effect of Moringa oleifera Lam on paracetamolinduced hepatotoxicity. Ind. J. Pharmaceutical Sci. 60: 33-35.

Russell, T.A. (2004). Comparison of sensory properties of whey and soy protein concentrates and isolates. Food Science, vol. Master of Science (p. 132). North Carolina State University. North Carolina State USA.

Sacks, Lichtenstein, A., Van Horn, L. Harris W., KrisEtherton, P., Winston, M. (2006). "Soy Protein Isoflavones and Cardiovascular Health". American Heart Association Nutrition Committee.

Scheiwger. R.G. (1974). Soy protein concentrate and isolate in comminuted meat system. J. Am Oil Chem Soc. 51:192A- 194A.

Vaisey, M., Tassor, L., McDonald, B.E. and Young, O.G. (1975). Performance of Fababean and Field Pea Protein Concentrates as Ground Beef Extenders. Can inst. Food Sci. techno. 8: 74.

Waggle, D.H., Decker, C.D. and Kolar, C.W. (1981). Soy products in meat, poultry and sea food. J. Am. Oil Chem. Soc. 20:341-342

Watts, B.M., Yimaki, G.L., Jeffery, L.E., Elias, L.G. (1989). Basic Sensory Methods for food Evaluation. Copyright International Development Research Centre. P. 20 